\title{
Clean Cities Annual Metrics Report 2007
}

Technical Report NREL/TP-540-43858

September 2008

C. Johnson and P. Bergeron
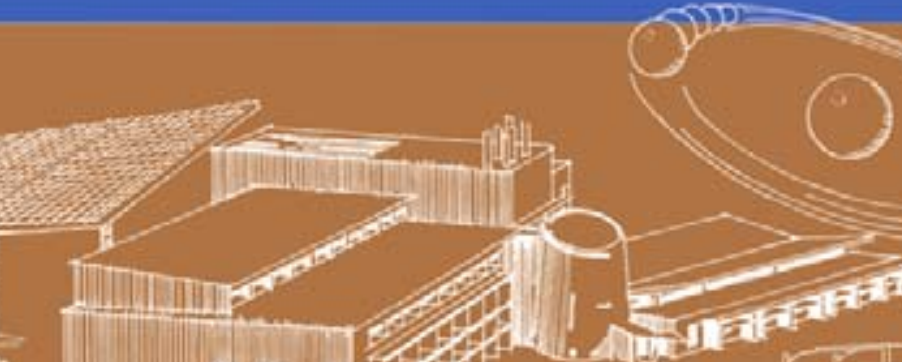


\section{Clean Cities Annual Metrics Report 2007}

C. Johnson and P. Bergeron

Prepared under Task No. FC08.0032

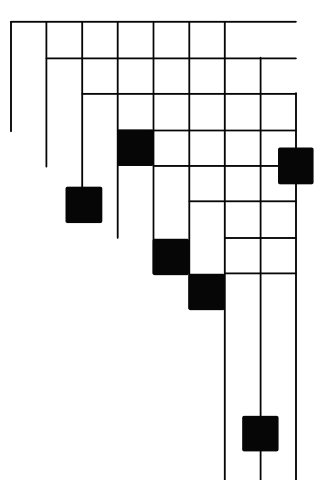

National Renewable Energy Laboratory

1617 Cole Boulevard, Golden, Colorado 80401-3393

303-275-3000 • www.nrel.gov

Operated for the U.S. Department of Energy

Office of Energy Efficiency and Renewable Energy

by Midwest Research Institute $\bullet$ Battelle

Contract No. DE-AC36-99-G010337 


\section{NOTICE}

This report was prepared as an account of work sponsored by an agency of the United States government. Neither the United States government nor any agency thereof, nor any of their employees, makes any warranty, express or implied, or assumes any legal liability or responsibility for the accuracy, completeness, or usefulness of any information, apparatus, product, or process disclosed, or represents that its use would not infringe privately owned rights. Reference herein to any specific commercial product, process, or service by trade name, trademark, manufacturer, or otherwise does not necessarily constitute or imply its endorsement, recommendation, or favoring by the United States government or any agency thereof. The views and opinions of authors expressed herein do not necessarily state or reflect those of the United States government or any agency thereof.

Available electronically at http://www.osti.gov/bridge

Available for a processing fee to U.S. Department of Energy and its contractors, in paper, from:

U.S. Department of Energy

Office of Scientific and Technical Information

P.O. Box 62

Oak Ridge, TN 37831-0062

phone: 865.576 .8401

fax: 865.576 .5728

email: mailto:reports@adonis.osti.gov

Available for sale to the public, in paper, from:

U.S. Department of Commerce

National Technical Information Service

5285 Port Royal Road

Springfield, VA 22161

phone: 800.553 .6847

fax: 703.605.6900

email: orders@ntis.fedworld.gov

online ordering: http://www.ntis.gov/ordering.htm 


\section{Table of Contents}

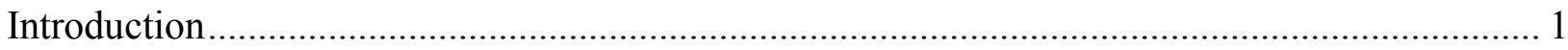

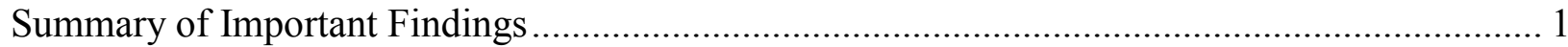

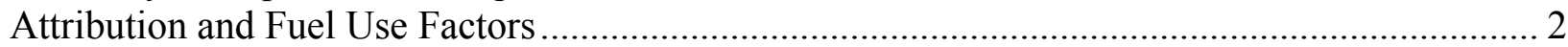

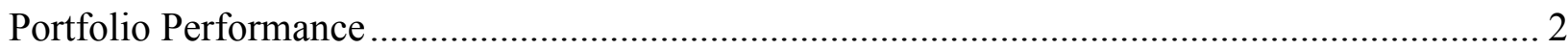

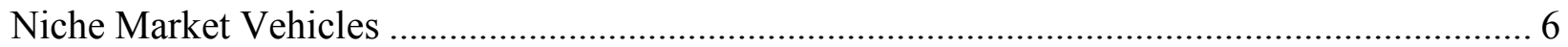

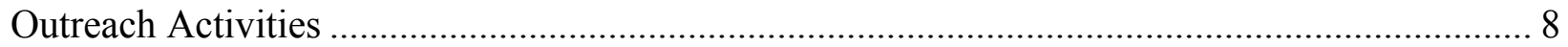

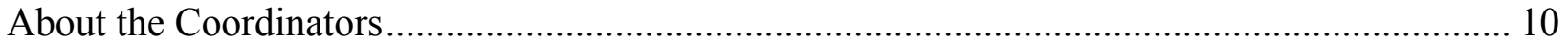

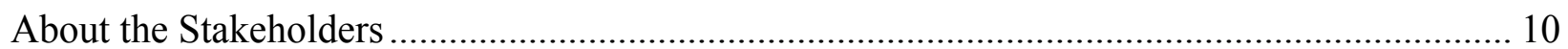

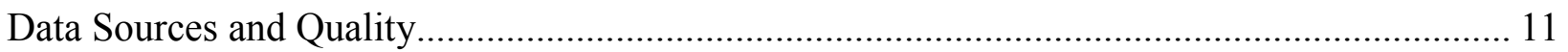

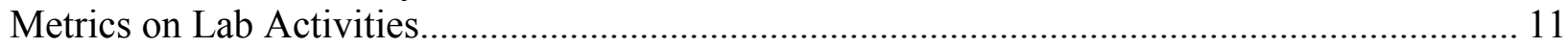

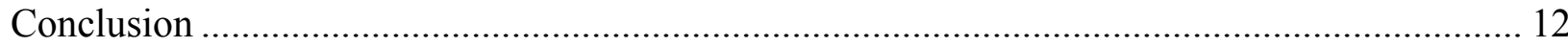

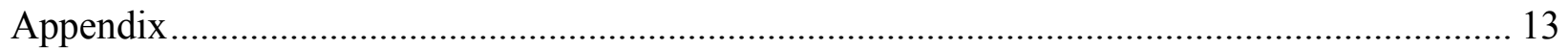

\section{List of Figures}

Figure 1. Annual Displacement Projection to Meet 2005 Goal and Actual Progress..................... 3

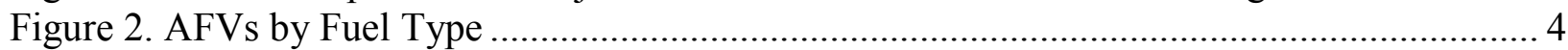

Figure 3. AFV Displacement by Each Fuel (in Thousand GGE) …………………..................... 5

Figure 4. Displacement Due to Idle Reduction Projects (in Million GGE) ..................................... 6

Figure 5. Percentage of Total AFVs and HEVs by Niche Market............................................... 7

Figure 6. Number of Outreach Activities Split Among Audience Types ...................................... 9

Figure 7. Number of Outreach Activities by Technology Type ……......................................... 9

Figure 8. Data Quality Responses by Data Source ……………………………………….......... 11

\section{List of Tables}

Table 1. Petroleum Displacement of Each Portfolio Element ......................................................... 3

Table 2. Number and Type of Vehicles for Each Niche Market (Updated) ................................... 7

Table 3. Number of Coalitions with Projects that Include Non-Road Vehicles or Equipment...... 8

Table 4. Results for the Seven Types of Outreach Activities ....................................................... 8

Table 5. Breakdown of Grants by Number and Value................................................................. 10 


\section{Introduction}

Each year, the U.S. Department of Energy (DOE) asks Clean Cities coordinators to submit an annual report of their activities and accomplishments for the previous calendar year. Data and information are submitted to an online database that is maintained as part of the Alternative Fuels and Advanced Vehicles Data Center (AFDC) at the National Renewable Energy Laboratory (NREL). Coordinators submit a range of data that characterize the membership, funding, projects, and activities of their coalitions. They also submit data about sales of alternative fuel blends, deployment of alternative fuel vehicles (AFVs), hybrid electric vehicles (HEVs), idle reduction initiatives, and fuel economy activities. NREL analyzes the data and translates them into gasoline reduction impacts, which are summarized in this report.

Eighty-six of the 87 coalitions that were active throughout 2007 submitted their reports - a response rate of $99 \%$. This reflects an increase from the 2006 report response rate of $94 \%$. The appendix to this report lists the coalitions that submitted their 2007 reports. Coalition coordinators assembled the data based on voluntary reports from their stakeholders - the private and public entities that are members of the coalitions. As such, these reports represent just a subset of the activities going on throughout the nation, but they are an important indicator of the impact of the coalitions and petroleum-reducing technologies at the local level.

In addition to the coordinator reports, metrics are gathered about activities funded by the Clean Cities Program at NREL and Oak Ridge National Laboratory (ORNL). NREL provides a range of technical data, tools, and resources to support coalitions in their efforts to accelerate the use of alternative fuels and other technologies. ORNL produces the Fuel Economy Guide, the Web site fueleconomy.gov, and provides a range of public information related to fuel economy. Metrics of the use and impact of these resources are also presented in this report.

A detailed breakdown of the data used to produce this and previous reports can be accessed at www.eere.energy.gov/afdc/data/cleancities.html.

\section{Summary of Important Findings}

Approximately 375 million gallons of gasoline were displaced ${ }^{1}$ through the Clean Cities efforts in 2007-4\% more than in 2006. This displacement represents the combined results of the activities reported by coalitions (as analyzed by NREL) and the impacts of the Fuel Economy Guide and related activities (as estimated by ORNL).

Once again, AFVs accounted for the largest share (84\%) of the total displacement. The use of biofuels (ethanol and biodiesel) as fuels for AFVs and in low-level blends displaced 118 million gallons, or $31 \%$ of the total 375 million. Fuel economy impacts were responsible for displacing 86 million gallons (combined impacts of coalition and ORNL activity), and idle reduction and $\mathrm{HEV}$ technologies combined to displace 23 million gallons of gasoline.

\footnotetext{
${ }^{1}$ The fuel displaced includes both gasoline and diesel. Fuel displacement in this report has been converted to gasoline gallon equivalents (GGE) using the lower heating value ratio of the fuels.
} 
In addition to petroleum displacement, a remarkable achievement of the coalitions was their ability to leverage the DOE investment. In 2007, the coalitions won 199 grants worth a total of $\$ 131.8$ million, plus another $\$ 50.8$ million in leveraged funds from coalition members. This represents a 26:1 leveraging of the program budget in FY 2007. This level of funding enabled the coordinators to spend more than 100,000 hours pursuing Clean Cities' goals, which is like having a national network of 48 full-time technical sales professionals working to reduce U.S. dependence on oil.

Coordinators entered 1,252 outreach activities for 2007, which were estimated to reach 42 million people. Most often, AFVs were the subject of these activities, as has generally been the case in the past. As was the case last year, fuel blends were the second most popular outreach subject. Together, AFVs and blends were the subject of $60 \%$ of all outreach activities.

\section{Attribution and Fuel Use Factors}

To improve the link between coalition activities and end results, the coalition annual report includes an attribution factor to account for the percentage of a project's outcome that might be due to coalition activities rather than those of other participants in the project. This was used in the estimate of impacts for fuel economy, idle reduction, alternative fuel blend, and outreach projects. Coordinators entered the percentage of the project's outcome that they thought they were responsible for, and the project's overall outcome was multiplied by that percentage to determine the coalitions' impact. Although subjective, this method does attempt to address the issue of attribution where coalitions are one of multiple partners involved in a project.

As introduced in last year's survey, coordinators had the option to enter the amount of alternative fuel used by the AFVs they reported. If they knew this amount, they could enter it instead of using the default values on the form to convert numbers of AFVs reported into an amount of fuel saved.

\section{Portfolio Performance}

Coordinators from 86 of the 87 Clean Cities coalitions submitted information on all five technologies in the Clean Cities portfolio. The data were analyzed and converted into an amount of gasoline displaced by each element and reported in units of gasoline-gallon equivalents (GGE) - the amount of energy contained in a gallon of gasoline.

As shown in Table 1, about 294 million GGE were displaced through Clean Cities coalition efforts in 2007. This is $2.4 \%$ higher than the total 2006 displacement of 287 million GGE, and it averages to 3.4 million GGE per responding coalition. Petroleum displaced by ORNL's fuel economy guide then boosts the total Clean Cities effort by 80.6 million GGE, for a total displacement of 375 million GGE. 
Table 1. Petroleum Displacement of Each Portfolio Element

\begin{tabular}{|l|c|c|c|}
\hline \multicolumn{1}{|c|}{ Technology } & Million GGE & $\begin{array}{c}\text { Percent of } \\
\text { Coalitions' Total }\end{array}$ & $\begin{array}{c}\text { Change from } \\
\text { Last Year }\end{array}$ \\
\hline AFV & 247 & $84 \%$ & $-2 \%$ \\
\hline Blends & 20 & $7 \%$ & $+93 \%$ \\
\hline Hybrid Electric Vehicles & 17 & $6 \%$ & $+94 \%$ \\
\hline Idle Reduction & 6 & $2 \%$ & $-28 \%$ \\
\hline Fuel Economy & 5 & $2 \%$ & $-31 \%$ \\
\hline \hline Coalitions Total & 294 & $100 \%$ & $+2 \%$ \\
\hline ORNL Fuel Economy & 81 & - & $+11 \%$ \\
\hline \hline Grand Total & 375 & - & $+4 \%$ \\
\hline
\end{tabular}

In 2005, Clean Cities set a goal of displacing 2.5 billion GGE per year by 2020. The data presented in this report show that Clean Cities is on schedule to exceed this goal. Progress is being tracked in Figure 1 below, where the path set forth to achieve the 2005 goal is shown as the blue dotted line and actual displacement is being tracked as the black solid line.

Achieving the goal of 2.5 billion gallons displaced in 2020 has become easier because of the progress made in the past two years. When the goal was set, a compounded annual growth rate of $16.6 \%$ was required. This requirement has now been reduced to $15.7 \%$ to meet the 2020 goal. Maintaining this annual growth rate seems achievable given that the historic annual growth rate has been $28 \%$.

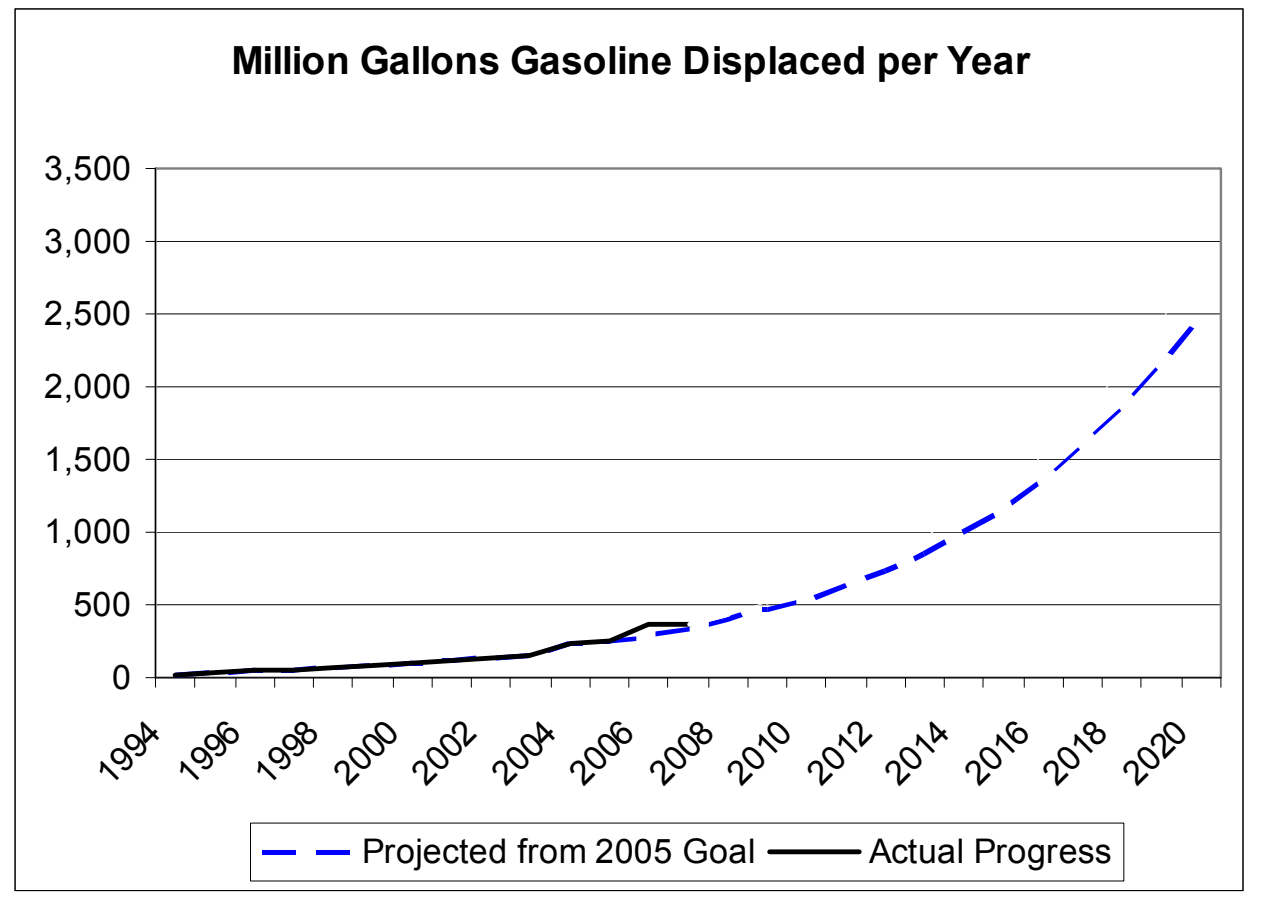

Figure 1. Annual Displacement Projection to Meet 2005 Goal and Actual Progress 


\section{Alternative Fuel Vehicles}

As shown in Table 1, AFVs accounted for the displacement of 247 million gallons, or $84 \%$ of the total portfolio displacement. This is a decrease of $2 \%$ in comparison to 2006 fuel displacement by AFVs.

The 2\% drop in AFV fuel displacement from 2006 to 2007 is likely caused by increased accuracy of this year's report. Coordinators were encouraged to estimate the actual amount of fuel used rather than use defaults based on average fuel-use estimates. This makes an especially large difference for vehicles that can use both alternative and petroleum fuels, which helps to explain the $8.3 \%$ reduction that occurred between 2006 and 2007 in the use of biofuels (e.g., E85, 85\% ethanol and 15\% gasoline; B20, 20\% biodiesel and $80 \%$ conventional diesel; and B100, neat biodiesel).

In 2007, coalitions reported a total inventory of nearly 579,000 AFVs split among the vehicle types (as shown in Figure 2). The share of the fleet capable of using E85 increased from $46 \%$ in 2006 to $67 \%$ in 2007 .

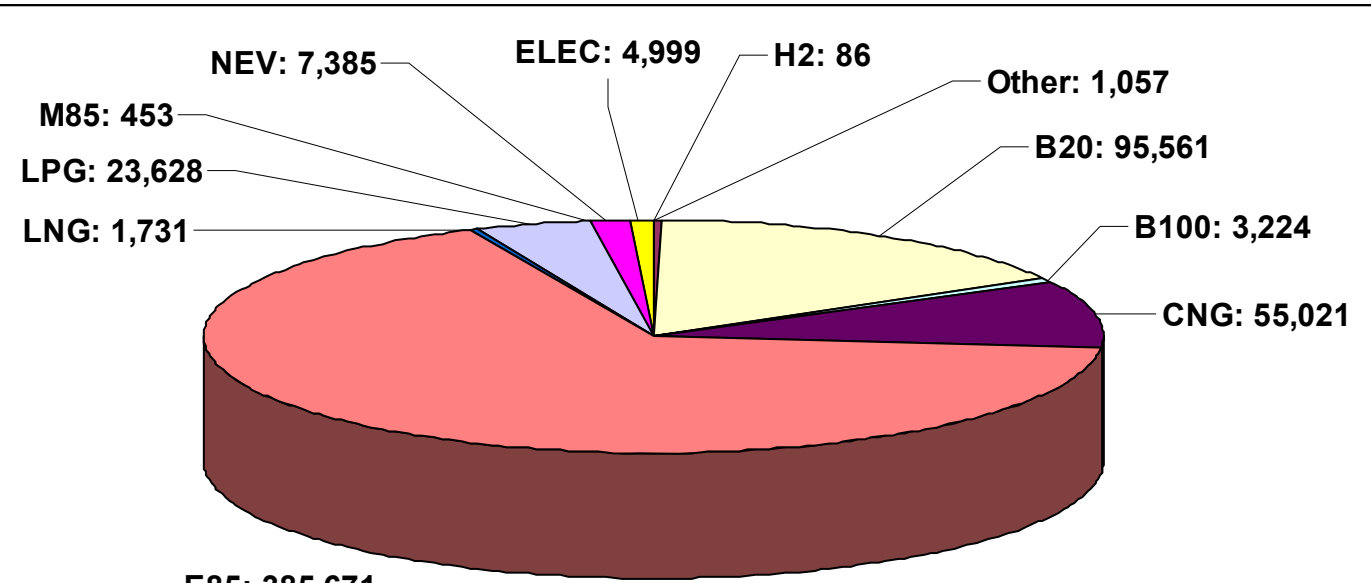

E85: 385,671

Figure 2. AFVs by Fuel Type

Figure 3 shows the total GGE displaced in AFVs by fuel type. Compressed natural gas (CNG) remains at the top of the list, accounting for $41 \%$ of the total AFV displacement. Biodiesel accounts for the next largest displacement, as B20 and B100 combine for $25 \%$ of the total. E85 accounts for only $15 \%$ of the AFV displacement despite the fact that $67 \%$ of the AFVs reported by coalitions can use E85. 


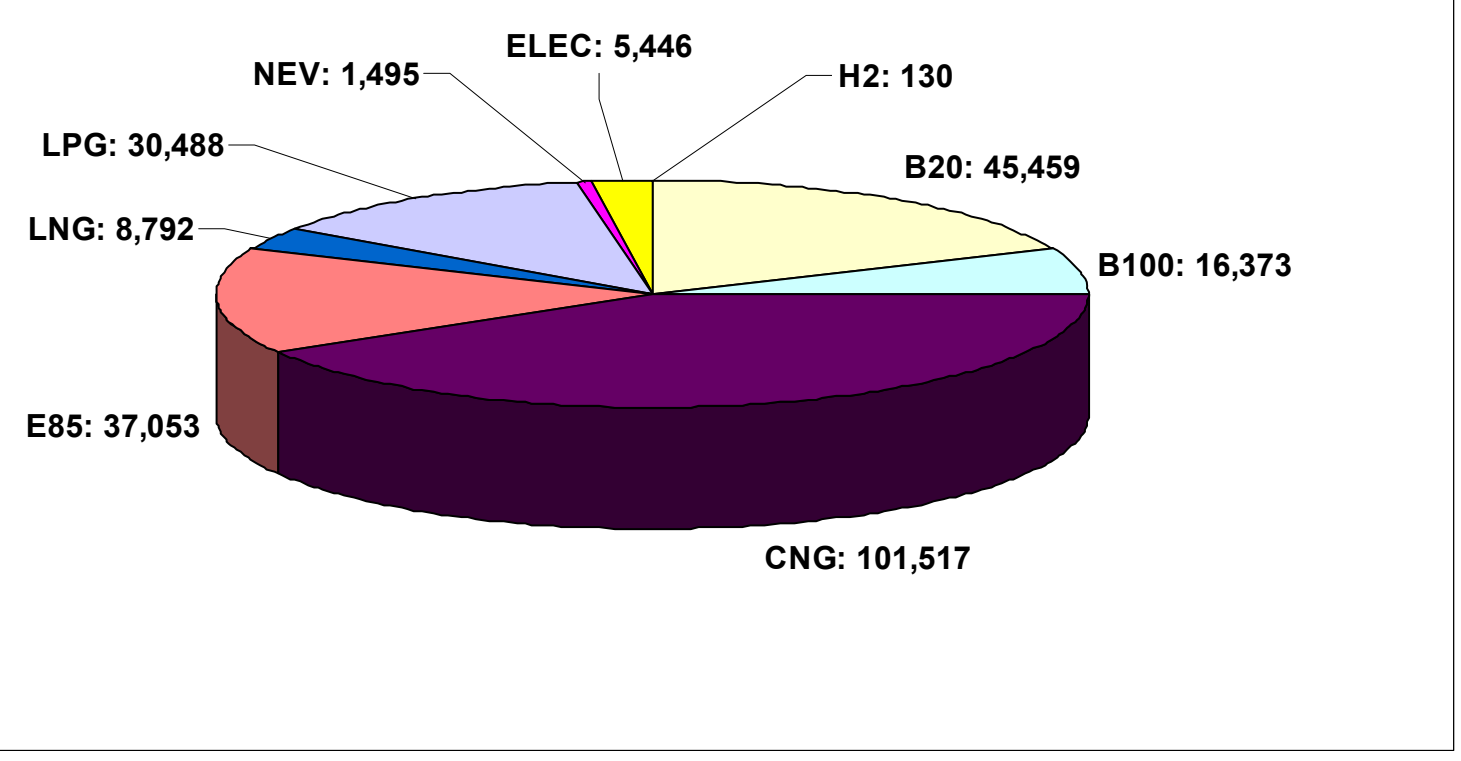

Figure 3. AFV Displacement by Each Fuel (in Thousand GGE)

Sixty-nine percent of the total displacement due to AFVs was from alternative fuel use in heavyduty vehicles - an increase from $66 \%$ last year. The use of biodiesel and liquefied natural gas (LNG) is confined almost exclusively to heavy-duty vehicles. Roughly three-fourths of the displacement from hydrogen, CNG, and liquefied petroleum gas (LPG) occurred in heavy-duty vehicles. Approximately two-thirds of the displacement from electric vehicles comes from these heavy-duties.

\section{Hybrid Electric Vehicles}

The number of HEVs resulting from Clean Cities efforts approached 82,000 in 2007, about 12\% of the total vehicles (AFVs plus HEVs) reported in the 2007 questionnaire. Using these vehicles rather than conventional vehicles saved 16 million gallons in 2007, an 83\% increase from 2006. Plug-in HEVs (PHEVs) seem to be catching on in Clean Cities coalitions, as their numbers rose from 105 in 2006 to 896 in 2007. Like fuel economy measures, higher gasoline prices seem to have been a major factor in the increased displacement by HEVs and PHEVs in 2007.

\section{Fuel Economy}

This category includes projects to reduce vehicle miles traveled (VMT) as well as improvements in vehicle fuel economies (FE). The 2007 survey shows that the amount of petroleum displacement was roughly the same from projects to improve FE (2.4 million GGE) and from projects to reduce VMT (2.7 million GGE). However, this roughly equal displacement came from a very different number of projects. In fact, there were twice as many VMT projects (23) as FE projects (11).

The trends for these two types of projects are also very different. In 2007, VMT projects displaced $41 \%$ more petroleum than they did in 2006. In contrast, 2007 FE projects displaced $57 \%$ less petroleum than they did in the previous year. 


\section{Idle Reduction}

Estimated fuel displacement for idle reduction technologies was 6.0 million GGE in 2007. Idle reduction technologies include truck-stop electrification, onboard idle reduction, and idle reduction policies. As shown in Figure 4, onboard idle reduction technologies accounted for 41\% of the displacement estimated for the three technologies, truck stop electrification accounted for $31 \%$, and policies accounted for $28 \%$.

The total fuel displaced by idle reduction (6 million GGE) is down from 8.4 million in 2006 . This difference is due to the large (72\%) reduction in policies enacted. Both truck stop electrification and onboard idle reduction show substantial increases in displacement between 2006 and 2007 (60\% and 97\%, respectively).

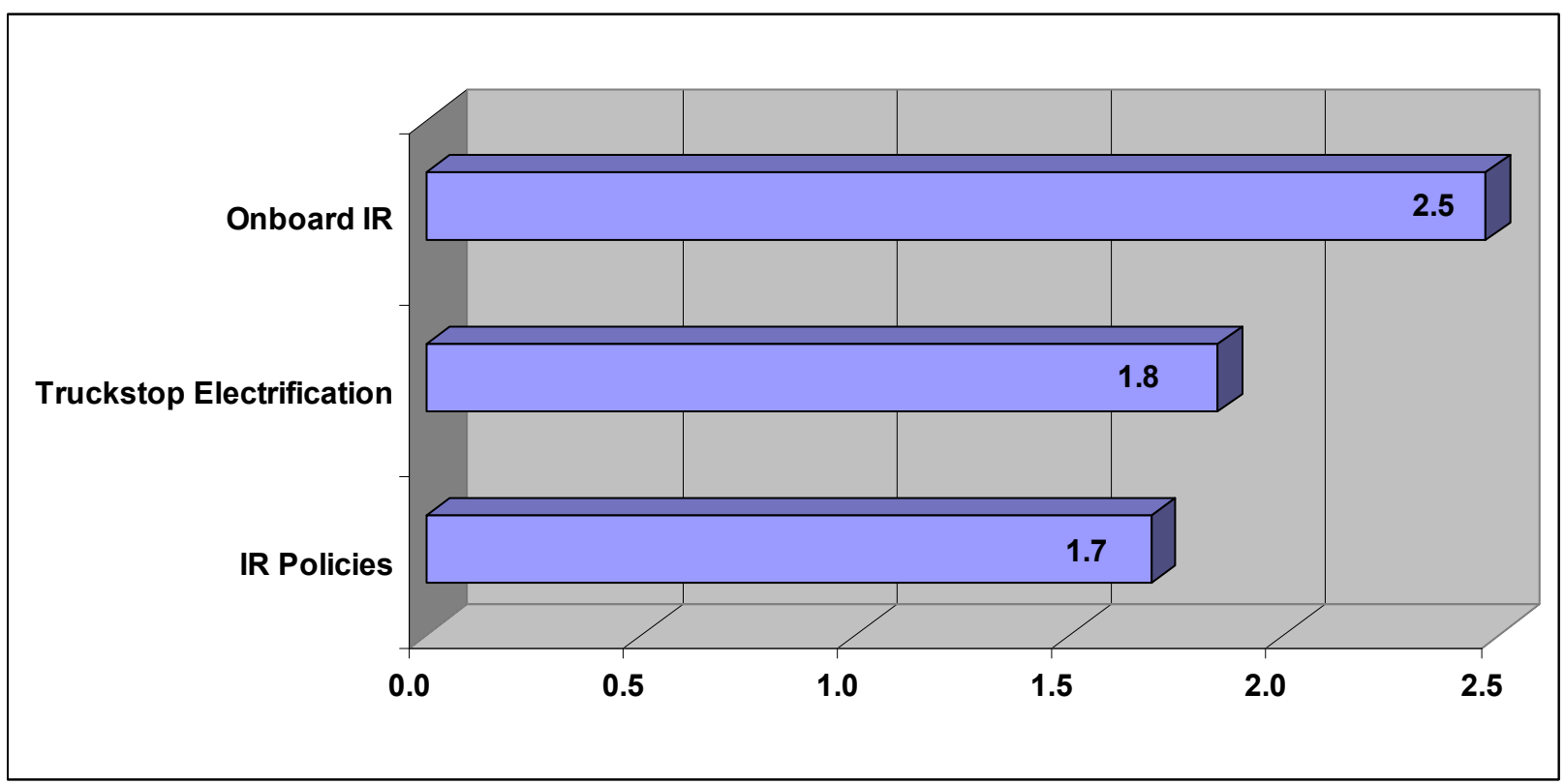

Figure 4. Displacement Due to Idle Reduction Projects (in Million GGE)

\section{Blends}

Clean Cities' efforts to promote the use of alternative fuel blends saved 20 million GGE in 2007. The use of low-level biodiesel blends saved almost 6 million GGE, and the use of E10 saved the remaining 14 million. This is a small fraction of the roughly 6.7 billion GGE of ethanol sold in blends in 2007, but it represents the amount that the coalitions believe they were influential in introducing into the marketplace.

\section{Niche Market Vehicles}

The questionnaire also asked coordinators to categorize their AFVs and HEVs into key niche market fleets. As shown in Table 2 and Figure 5, the state government light-duty vehicle (LDV) fleets contain the largest number of vehicles and account for $20 \%$ of the total niche market vehicle population. This category is followed closely by the school bus niche (18\%) and local government LDVs (15\%). The largest change from last year is the decrease in transit vehicles, 
from $54 \%$ to $11 \%$ of all niche market vehicles. This decrease occurred specifically in B20 transit buses, and it likely stems from one or two large fleets deciding to run their buses on diesel instead of B20 in 2007.

Table 2. Number and Type of Vehicles for Each Niche Market (Updated)

\begin{tabular}{|r|r|r|r|r|r|r|r|r|r|r|r|r|r|}
\hline Niche Market & B20 & CNG & E85 & HYB & NEV & LPG & LNG & ELEC & B100 & H2 & PHYB & OTHER & TOTAL \\
\hline State Govt LDVs & 6,560 & 640 & 6,718 & 662 & 16 & 62 & 0 & 9 & 3 & 3 & 2 & 0 & 14,675 \\
\hline School Bus & 6,414 & 575 & 0 & 3 & 0 & 993 & 0 & 0 & 0 & 0 & 1 & 5,712 & 13,698 \\
\hline Local Govt LDVs & 1,981 & 950 & 964 & 6,240 & 662 & 115 & 0 & 178 & 0 & 7 & 1 & 24 & 11,122 \\
\hline Transit & 1,074 & 3,608 & 0 & 621 & 2,000 & 304 & 344 & 16 & 234 & 3 & 1 & 14 & 8,219 \\
\hline Waste haulers & 4,357 & 201 & 0 & 0 & 0 & 6 & 952 & 0 & 0 & 0 & 0 & 0 & 5,516 \\
\hline Off-road vehicles & 4,357 & 50 & 200 & 0 & 46 & 175 & 0 & 323 & 27 & 3 & 0 & 100 & 5,281 \\
\hline Utility & 1,132 & 2,687 & 389 & 259 & 8 & 21 & 0 & 88 & 100 & 3 & 2 & 0 & 4,689 \\
\hline Deliv/Transport & 357 & 1,237 & 45 & 1,172 & 29 & 1,057 & 0 & 128 & 153 & 30 & 0 & 11 & 4,219 \\
\hline USPS & 0 & 283 & 2,142 & 0 & 0 & 0 & 0 & 22 & 0 & 0 & 0 & 0 & 2,447 \\
\hline Airport & 20 & 1,112 & 22 & 43 & 104 & 114 & 48 & 155 & 0 & 8 & 0 & 1 & 1,627 \\
\hline Police & 836 & 89 & 638 & 3 & 10 & 0 & 0 & 3 & 0 & 0 & 0 & 10 & 1,589 \\
\hline Maintenance & 600 & 317 & 51 & 9 & 192 & 82 & 0 & 37 & 0 & 1 & 0 & 0 & 1,289 \\
\hline US Parks & 482 & 8 & 27 & 34 & 0 & 8 & 0 & 16 & 0 & 0 & 0 & 0 & 575 \\
\hline Shuttle & 72 & 203 & 2 & 5 & 0 & 21 & 0 & 0 & 13 & 3 & 0 & 0 & 319 \\
\hline Total & 28,242 & 11,960 & 11,198 & 9,051 & 3,067 & 2,958 & 1,344 & 975 & 530 & 61 & 7 & 5,872 & 75,265 \\
\hline
\end{tabular}

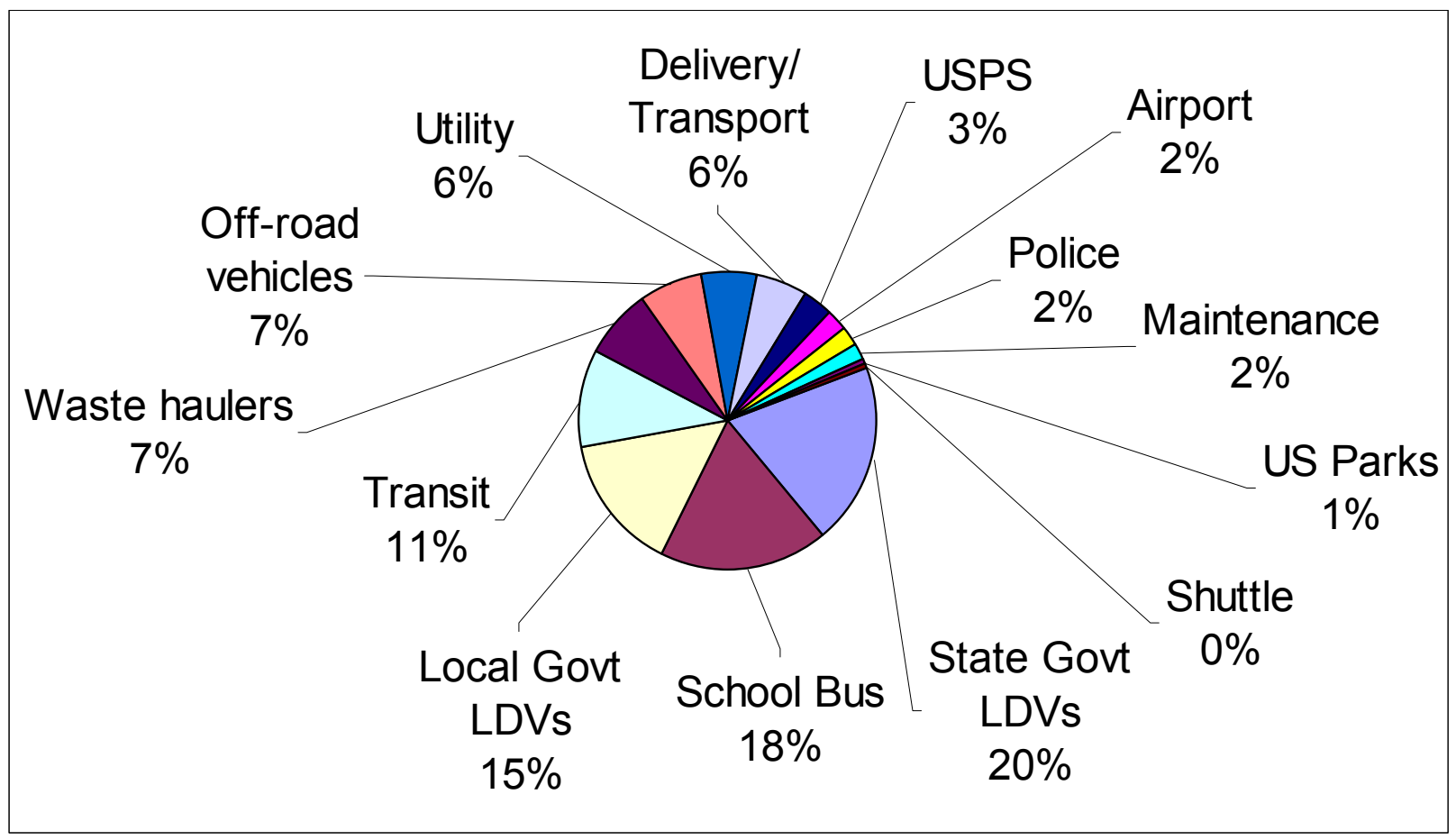

Figure 5. Percentage of Total AFVs and HEVs by Niche Market

Coalitions were asked which type of non-road equipment or vehicles they had used in their projects. They were provided six categories of vehicles and equipment from which to choose, 
and their responses are shown in Table 3. Most of these categories are self-descriptive except for construction equipment (such as cranes and earth movers) and recreation equipment (such as jet skis, snow mobiles, and all-terrain vehicles).

Table 3. Number of Coalitions with Projects that Include Non-Road Vehicles or Equipment

\begin{tabular}{|l|c|}
\hline \multicolumn{1}{|c|}{ Category } & Number of Coalitions \\
\hline Construction equipment & 23 \\
\hline Forklifts & 15 \\
\hline Railroads & 10 \\
\hline Ships & 6 \\
\hline Recreational equipment & 5 \\
\hline Planes & 2 \\
\hline Other & 21 \\
\hline \hline Total & 82 \\
\hline
\end{tabular}

\section{Outreach Activities}

Outreach activities were classified into seven categories, as shown in Table 4. A total of 1,252 activities were reported and were estimated to reach nearly 42 million people - twice the number reached last year. Advertisements and media events dominated the field, combining to represent more than $86 \%$ of the total number of people reached. However, these numbers do not necessarily reflect the actual impact that each event had on the audience. For example, extended personal contact at an Advancing the Choice event might have had a much greater impact than an advertisement heard on the radio.

Table 4. Results for the Seven Types of Outreach Activities

\begin{tabular}{|l|r|r|r|r|}
\hline \multicolumn{1}{|c|}{ Activity Type } & \multicolumn{1}{|c|}{$\begin{array}{c}\text { Persons } \\
\text { Reached }\end{array}$} & $\begin{array}{c}\text { \% of All } \\
\text { People } \\
\text { Reached }\end{array}$ & $\begin{array}{c}\text { No. of } \\
\text { Activities }\end{array}$ & $\begin{array}{c}\text { \% of All } \\
\text { Activities }\end{array}$ \\
\hline Advertisement & $23,654,749$ & $56.7 \%$ & 27 & $2.2 \%$ \\
\hline Media Event & $12,416,369$ & $29.8 \%$ & 164 & $13.1 \%$ \\
\hline Literature Distribution & $2,176,193$ & $5.2 \%$ & 238 & $19.0 \%$ \\
\hline Legislation & $1,503,314$ & $3.6 \%$ & 39 & $3.1 \%$ \\
\hline Meeting & $1,350,424$ & $3.2 \%$ & 621 & $49.6 \%$ \\
\hline Advancing the Choice & 497,708 & $1.2 \%$ & 147 & $11.7 \%$ \\
\hline Web Site & 134,300 & $0.3 \%$ & 16 & $1.3 \%$ \\
\hline Total for All Types & $41,733,057$ & $100.0 \%$ & 1,252 & $100.0 \%$ \\
\hline
\end{tabular}

Coordinators were asked to judge how much they thought they were responsible for the number of people reached in each event in contrast to the contributions of other event sponsors and participants. An analysis of the responses shows that, on average, coordinators felt they were responsible for $58 \%$ of the 42 million people reached. 
Figure 6 illustrates the types of audiences that the 1,252 outreach activities attempted to reach. Any one activity could be aimed at more than one audience, and in fact about two-thirds of the activities targeted multiple audiences. The general public was most often cited as a target audience, followed by government vehicles and then fleets in general. Specialized applicationsairports, waste management, delivery trucks, utility trucks, and mass transit—were identified as audiences in one-third of the outreach activities. Other audiences were cited as audience types in $10 \%$ of the activities reported.

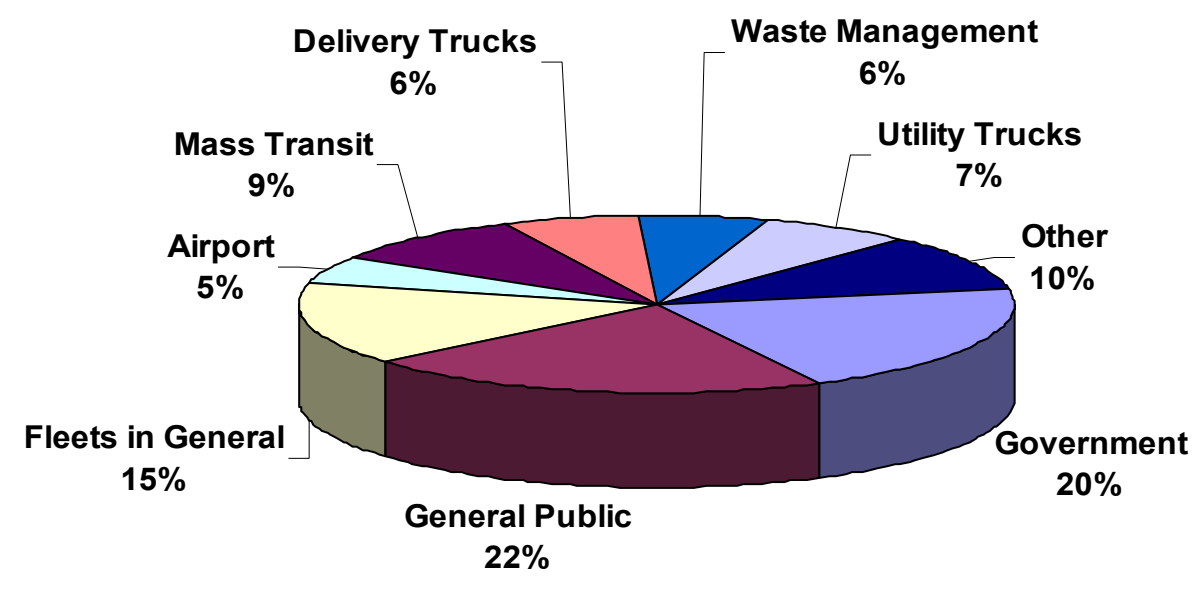

Figure 6. Number of Outreach Activities Split Among Audience Types

Figure 7 shows that AFVs were the technology most often targeted during outreach activities. This has generally been the case in the past. In general, the split among the technologies listed as targets are very similar this year to results from the 2006 questionnaire.

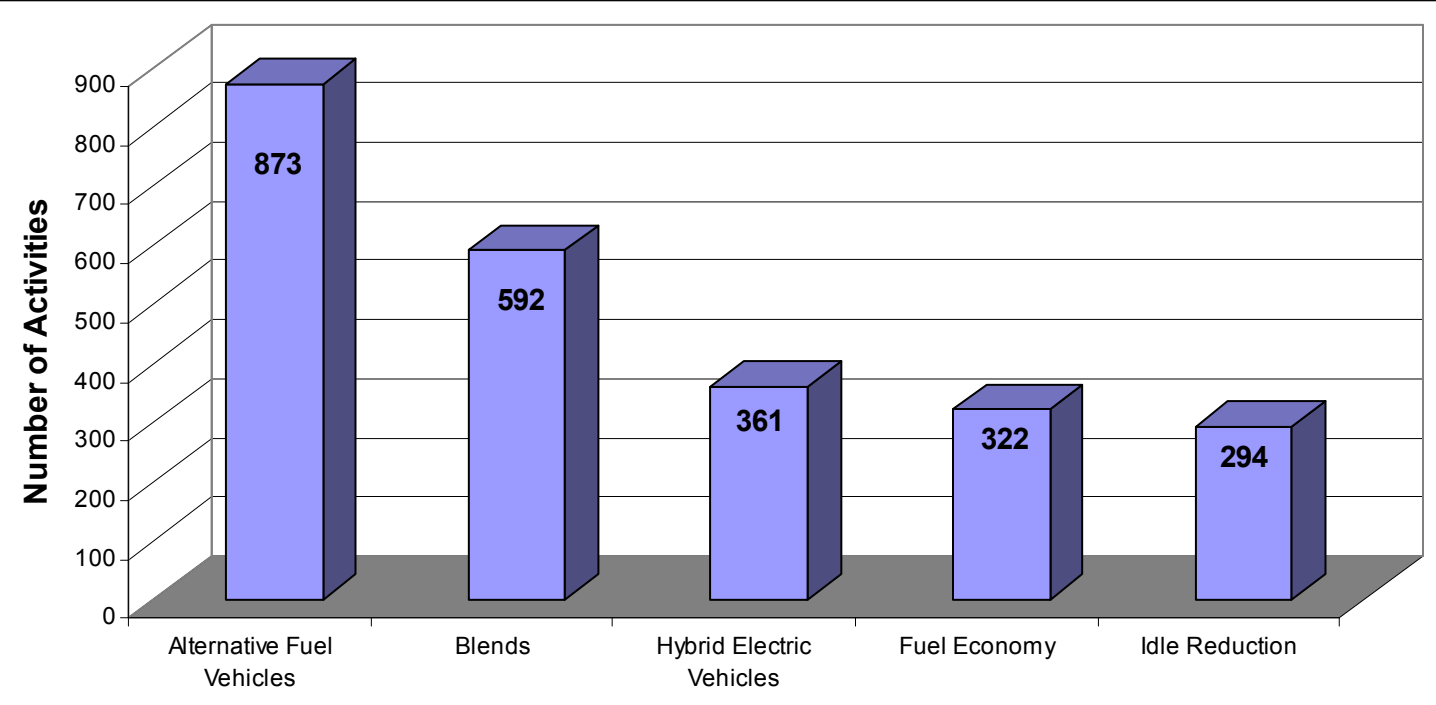

Figure 7. Number of Outreach Activities by Technology Type 


\section{About the Coordinators}

Coordinators reported spending a total of 1,852 hours per week on Clean Cities tasks. The average amount of time spent on Clean Cities business per week was 22 hours, and the median amount of time was 16 hours per week. Information on coordinator experience was also gathered in the questionnaire. On average, coordinators have been on the job for 4.6 years. Half have had more than 3 years of experience, and half have had 3 or fewer years of experience. The longest serving coordinator has accumulated 15 years of experience, and three have been with Clean Cities for 14 years. If all 87 coalition coordinators worked the average of 22 hours per week, then they spent almost 100,000 hours in all promoting the Clean Cities petroleum reduction portfolio in 2007. This is equivalent to having a national network of 48 full-time experienced technical sales professionals working to reduce U.S. dependence on oil.

\section{Coalition Grants}

In 2007, 66 coalitions reported receiving 199 grants worth a total of $\$ 131.8$ million. These coalitions also reported garnering another $\$ 50.8$ million in leveraged funds. Of the 199 grants, the value of nine grants each exceeded \$1 million. The grant with the highest value, \$56.6 million, was received by the Sacramento coalition. The funds will be used for AFV and advanced vehicle purchases. The Los Angeles coalition was awarded a grant of $\$ 45.9$ million for purchasing CNG buses.

Table 5 presents the breakdown of the number and value of grants reported by the coalitions.

Table 5. Breakdown of Grants by Number and Value

\begin{tabular}{|l|c|c|c|c|}
\hline \multicolumn{1}{|c|}{ Size Category } & Number & $\begin{array}{c}\text { \% of Total } \\
\text { Number }\end{array}$ & Total Value & $\begin{array}{c}\% \text { of Grand } \\
\text { Total Value }\end{array}$ \\
\hline$<\$ 50,000$ & 127 & $62 \%$ & $\$ 1,632,320$ & $1 \%$ \\
\hline$\$ 50,000-\$ 99,999$ & 19 & $10 \%$ & $\$ 1,388,266$ & $1 \%$ \\
\hline$\$ 100,000-\$ 499,999$ & 38 & $19 \%$ & $\$ 10,521,697$ & $8 \%$ \\
\hline$\$ 500,000-\$ 999,999$ & 6 & $3 \%$ & $\$ 2,341,712$ & $2 \%$ \\
\hline$\$ 1,000,000+$ & 9 & $5 \%$ & $\$ 115,962,151$ & $88 \%$ \\
\hline \hline Grand Total & & $100 \%$ & $\$ 131,796,146$ & $100 \%$ \\
\hline
\end{tabular}

\section{About the Stakeholders}

In 2007, 83 coalitions reported a total of 5,719 stakeholders, for an average of 69 per coalition. Furthermore, Clean Cities coalitions are growing: 719 of the 5,719 stakeholders were added in 2007 for an average of nearly nine new recruits per coalition.

Clean Cities is voluntary, and coalitions draw local stakeholders from the public and private sectors. Stakeholders include local, state, and federal agencies; public health and transportation departments; transit agencies and other government offices; and auto manufacturers, car dealers, fuel suppliers, public utilities, and professional associations. Coalitions reported that $48 \%$ of the 
total stakeholders were from the private sector. This represents a slight shift $(2 \%)$ from private to public stakeholders this year.

\section{Data Sources and Quality}

Gathering data is always challenging for the coordinators, as they rely on the voluntary reporting of their stakeholders and members. Therefore, the survey contains a couple of questions relating to coordinator sources and data quality. In these questions, coordinators were asked to rate the quality of their data as excellent, good, fair, or poor. The "cumulative" bar in Figure 8 presents the response breakdown for the 85 coordinators who answered the question. Fifty-six percent of the respondents classified their data as good, $25 \%$ as fair, $14 \%$ as excellent, and $2 \%$ as poor.

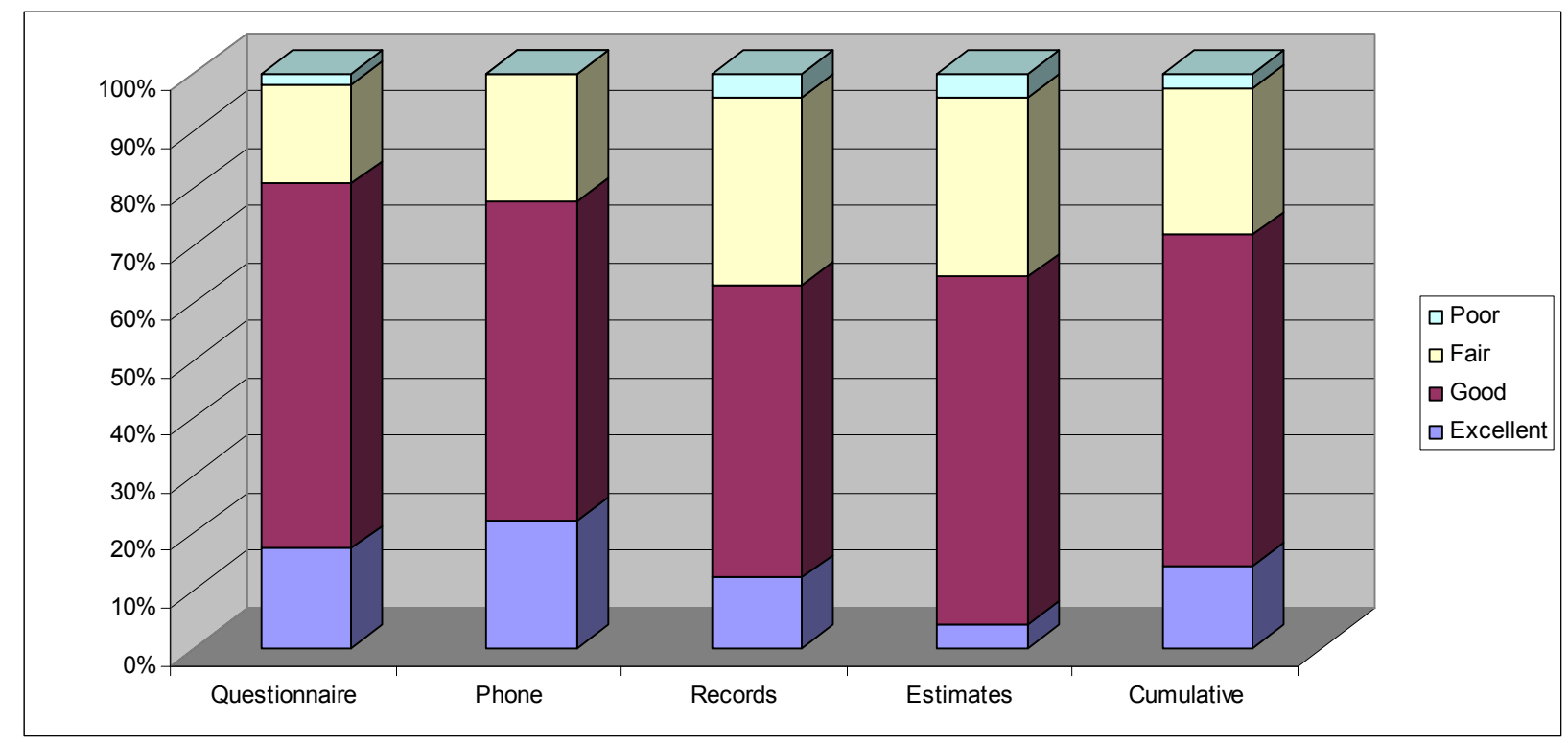

Figure 8. Data Quality Responses by Data Source

Coordinators were also asked where they obtained their data. They could choose one or more of the following: paper or electronic questionnaires to stakeholders, phone questionnaires of stakeholders, coalition records, or coalition estimates. All four methods were used equally- $24 \%$ to $26 \%$ of the time. Figure 8 shows that written surveys and phone interviews resulted in a higher rate of "excellent" and "good" data than did coalition records and estimates. This could be because the coordinators were more aware of the uncertainties in the data in the latter two options.

\section{Metrics on Lab Activities}

Both NREL and ORNL track the use of their information and resources. On behalf of Clean Cities, ORNL produces the Fuel Economy Guide based on fuel economy data developed by the Environmental Protection Agency. In addition, ORNL produces and maintains the www.fueleconomy.gov Web site, along with other print and educational activities related to fuel 
economy. Based on the distribution and use of these products and assumptions about their impact on consumer behavior, ORNL estimated that the impact of the materials on new car buyers, used car buyers, and car drivers exposed to Clean Cities products and projects resulted in a savings of 81 million gallons. The 81 million gallons is just the impact estimated for 2007. As a likely indication of increasing concerns among consumers about higher fuel prices, the annual 2007 savings are $11 \%$ higher than those estimated for 2006.

Online resources at NREL reached a large audience in 2007, as users accessed 7.2 million pages of information on the Clean Cities and AFDC Web sites. This usage number cannot be compared directly with the number for last year because of a change in accounting methods, but it appears to be a substantial increase. The sites at www.eere.energy.gov/cleancities and www.eere.energy.gov/afdc provide a range of resources to support coordinators, fleets, businesses, and local decision makers in their efforts to implement the technologies of the Clean Cities portfolio. The sites' content includes technical data, success stories, publications, and industry contacts, along with databases of federal and state incentives and laws, fuel station locations, available vehicles, and other information.

\section{Conclusion}

The metrics produced by Clean Cities help to quantify the impact of the program as a whole and of the activities of individual coalitions. Clean Cities believes the calculated impacts are a conservative measure of the program's overall impact, because the ability of coordinators to gather specific data about the impact of their activities is, by its very nature, limited. Furthermore, the ripple effect of their efforts in their local communities is difficult to measure. Clearly, though, the support of DOE and its national laboratories is enabling coalitions to coordinate the efforts of otherwise disparate groups and funding sources to accelerate the nation's progress toward petroleum displacement. 


\title{
Appendix
}

\section{Coalitions that Reported for $\mathbf{2 0 0 7}$}

\author{
Alamo Area
}

Ann Arbor Area Clean Cities Coalition

Antelope Valley

Atlanta Clean Cities

Capital Clean Cities of Connecticut, Inc.

Capital District-Albany

Central Arkansas

Central Coast Clean Cities Coalition

Central Indiana Clean Cities Alliance, Inc.

Central New York

Central Oklahoma Clean Cities

Central Texas Clean Cities

Centralina Clean Fuels Coalition

Chicago Area Clean Cities Coalition

Clean Fuels Ohio

Coachella Valley-Palm Springs

Colorado Springs Clean Cities Coalition

Columbia-Willamette, Inc.

Commonwealth Clean Cities Partnership

Dallas-Fort Worth

Delaware, State of

Denver

Detroit Area Clean Cities

Earth Day Coalition Clean Transportation Program

East Bay

East Tennessee Clean Fuels Coalition

East Texas Coalition

Eastern Sierra Regional Clean Cities Coalition, Inc.

Florida Space Coast Coalition

Genesee Region Clean Communities

Gold Coast

Granite State Clean Cities Coalition

Greater Baton Rouge Clean Cities Coalition

Greater Lansing Area Clean Cities

Greater Long Island Clean Cities Coalition

Greater New Haven Clean Cities, Inc.

Greater Philadelphia Clean Cities Program

Hampton Roads Clean Cities Coalition

Honolulu Clean Cities

Houston

lowa Clean Cities Coalition

Kansas City Regional Clean Cities Coalition

Land of Enchantment Clean Cities Corridor

Las Vegas, Inc.

Long Beach

Los Angeles Clean Cities Coalition

Maine Clean Communities 


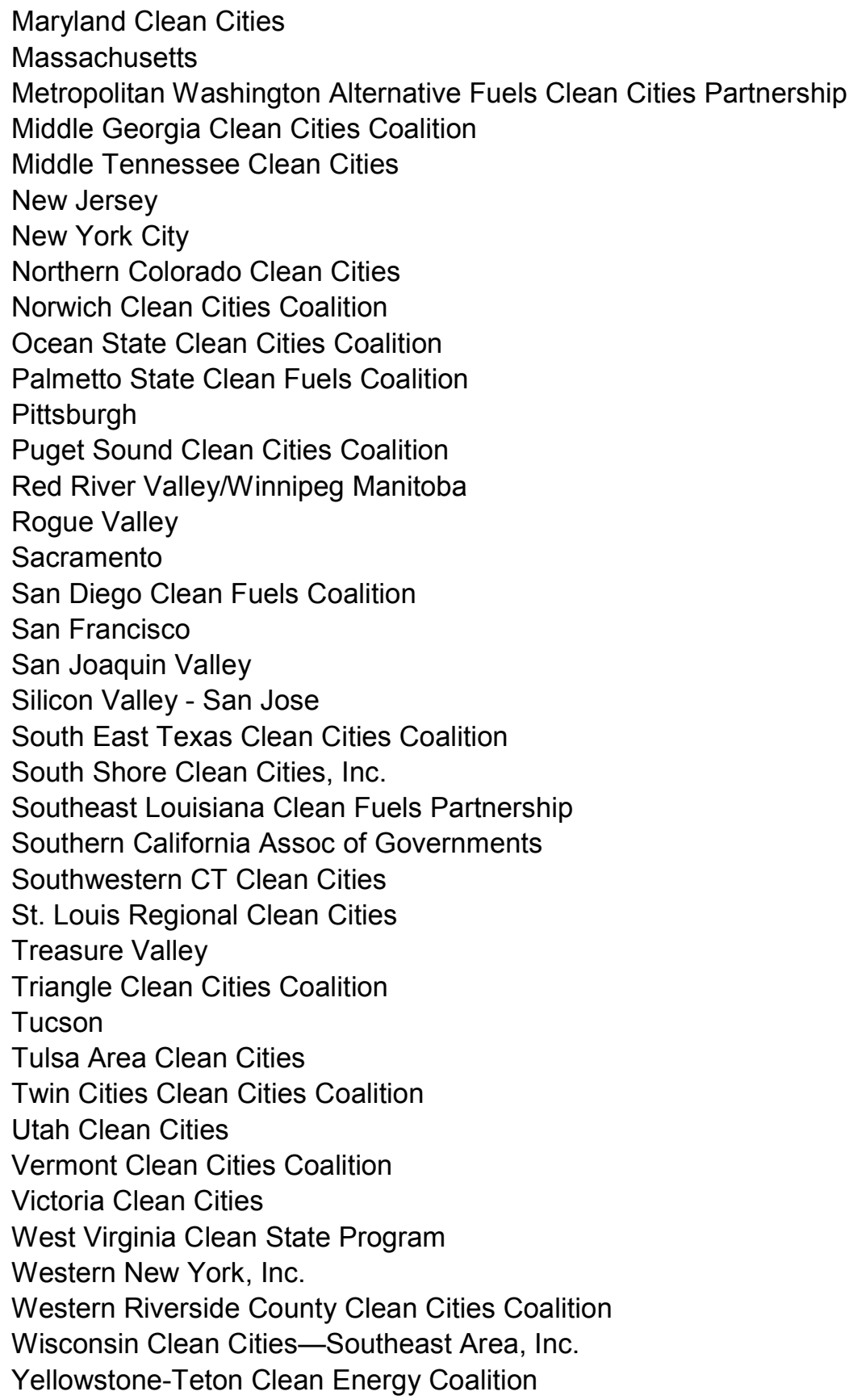




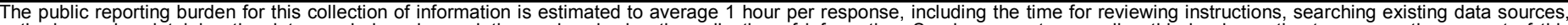

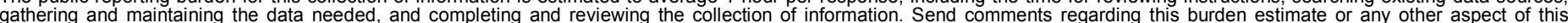

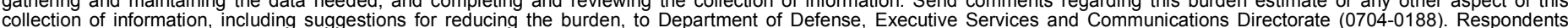

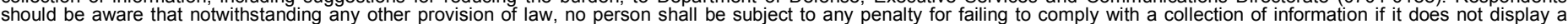

should be aware that notwithstanding

PLEASE DO NOT RETURN YOUR FORM TO THE ABOVE ORGANIZATION.

\begin{tabular}{l|l|l|l} 
1. REPORT DATE $(D D-M M-Y Y Y Y)$ & 2. & REPORT TYPE & 3. DATES COVERED (FrOm - TO)
\end{tabular}

September 2008

Technical Report

4. TITLE AND SUBTITLE

Clean Cities Annual Metrics Report 2007

5a. CONTRACT NUMBER

DE-AC36-99-G010337

5b. GRANT NUMBER

5c. PROGRAM ELEMENT NUMBER

6. AUTHOR(S)

C. Johnson and P. Bergeron

5d. PROJECT NUMBER

NREL/TP-540-43858

5e. TASK NUMBER

FC08.0032

5f. WORK UNIT NUMBER
7. PERFORMING ORGANIZATION NAME(S) AND ADDRESS(ES)

National Renewable Energy Laboratory

1617 Cole Blvd.

Golden, CO 80401-3393
8. PERFORMING ORGANIZATION REPORT NUMBER

NREL/TP-540-43858

9. SPONSORING/MONITORING AGENCY NAME(S) AND ADDRESS(ES)

10. SPONSOR/MONITOR'S ACRONYM(S) NREL

11. SPONSORING/MONITORING AGENCY REPORT NUMBER

12. DISTRIBUTION AVAILABILITY STATEMENT

National Technical Information Service

U.S. Department of Commerce

5285 Port Royal Road

Springfield, VA 22161

13. SUPPLEMENTARY NOTES

14. ABSTRACT (Maximum 200 Words)

This report summarizes the Department of Energy's Clean Cities coalition accomplishments in 2007, including petroleum displacement data, membership, funding, sales of alternative fuel blends, deployment of AFVs and HEVs, idle reduction initiatives, and fuel economy activities.

15. SUBJECT TERMS

Clean Cities; alternative fuel vehicles; AFVs; hybrid electric vehicles; HEVs; deployment; alternative fuel blends; idle reduction; fuel economy; coalitions; coordinators

\begin{tabular}{|c|c|c|c|c|}
\hline \multicolumn{3}{|c|}{ 16. SECURITY CLASSIFICATION OF: } & \multirow{2}{*}{$\begin{array}{l}\text { 17. LIMITATION } \\
\text { OF ABSTRACT } \\
\text { UL }\end{array}$} & \multirow{2}{*}{$\begin{array}{ll}\text { 18. } & \text { NUMBER } \\
\text { OF PAGES }\end{array}$} \\
\hline $\begin{array}{l}\text { a. REPORT } \\
\text { Unclassified }\end{array}$ & $\begin{array}{l}\text { b. ABSTRACT } \\
\text { Unclassified }\end{array}$ & $\begin{array}{l}\text { c. THIS PAGE } \\
\text { Unclassified }\end{array}$ & & \\
\hline
\end{tabular}

19a. NAME OF RESPONSIBLE PERSON

19b. TELEPHONE NUMBER (Include area code) 